\title{
XANTHINE OXIDASE INHIBITORY, ANTIHYPERURICEMIC, ANTI-INFLAMMATORY, ANTINOCICEPTIVE ACTIVITY OF $\alpha$-LIPOIC ACID IN GOUTY ARTHRITIS MODEL
}

\author{
BASIM JASIM HAMEED*, USAMA HAMID RAMADHAN \\ Department of Clinical Laboratories Sciences, College of Pharmacy, University of Basrah, Basrah, Iraq. Email: dr.basimjhs3791@gmail.com \\ Received: 16 August 2018, Revised and Accepted: 19 September 2018
}

\begin{abstract}
Objective: The current study was carried out to investigate the xanthine oxidase inhibitory, antihyperuricemic, anti-inflammatory, and antinociception activity of $\alpha$-lipoic acid (LA) in gouty model of rats.

Methods: Enzyme assay was done using bovine milk xanthine oxidase (XO). The XO inhibitory activity in vitro was performed using different doses of $\alpha$-LA, and the degree of XO inhibition was expressed as $\mathrm{IC}_{50}$. The antihyperuricemic activity of $\alpha$-LA was tested in the potassium oxonate-induced hyperuricemic rats for 7 consecutive days of oral treatment of 10,25 , and $50 \mathrm{mg} / \mathrm{kg}$ doses. The anti-inflammatory activity was achieved through monosodium urate crystal-induced inflammation hind paw model in mice. The antinociception effects of $\alpha$-LA were explored using both of writhings induced by acetic acid test and hot plate test.
\end{abstract}

Results: The study results revealed that the $\alpha$-LA has a potent activity of XO inhibition with IC $_{50}=2.93 \mu \mathrm{g} / \mathrm{mL}$. Furthermore, these results showed that all doses of $\alpha$-LA were able to significant reduce of each the following: Serum uric acid levels in the hyperuricemic rats, hind paw thickness of mice at all periods of time assessment, and writhings number in the acetic acid-induced writhing test, while, the same doses significantly increased the reaction latency in mice at hot plate test.

Conclusion: The $\alpha$-LA showed a significant effect on the evaluated models, and therefore it may be a promising agent for the treatment of gout since it possesses XO inhibitory, antihyperuricemic, anti-inflammatory, and antinociception activity.

Keyword: $\alpha$-lipoic acid, Xanthine oxidase inhibitor, Antihyperuricemic, Anti-inflammatory, Antinociceptive, Gout.

(C) 2018 The Authors. Published by Innovare Academic Sciences Pvt Ltd. This is an open access article under the CC BY license (http://creativecommons. org/licenses/by/4. 0/) DOI: http://dx.doi.org/10.22159/ajpcr.2018.v11i12.29160

\section{INTRODUCTION}

Uric acid (UA) is the ultimate product of nucleic acids degradation in most mammals consequently to the action of xanthine oxidase (XO) enzyme [1]. The two-thirds of UA pool comes from the breakdown of endogenous purines while the remaining quantity resulted from dietary (exogenous) purines. Human is the only organism from the rest of the mammals cannot convert UA to a more soluble compound, allantoin due to lack of the uricase enzyme [2]. Most of UA released from the human body by the renal tract while the gastrointestinal tract secretes the residual. Approximately $90 \%$ of the UA that secreted by the kidneys is reabsorbed by renal tubules into the blood. The absence of uricase enzyme association with massive reabsorption of filtered UA results in an elevation of UA levels in the human blood that is frequently ten-folds those of most other mammals [3]. As a result, high serum UA may be one of the main serious factors for developing of the hyperuricemia, which may lead to the occurrence of gout $[4,5]$. Hyperuricemia can be expressed as the blood UA level larger than the normal values in both females $(6 \mathrm{mg} / \mathrm{dL})$ and males $(7 \mathrm{mg} / \mathrm{dL})$, and it arises from underexcretion and/or overproduction of UA, where the main cause of hyperuricemia in the gouty patients is urate underexcretion [6,7]. Gouty arthritis is an inflammatory, metabolic defect affecting elderly men and postmenopausal women that originates due to the formation and accumulation of monosodium urate (MSU) crystals in the kidneys and inflamed joints [7]. Clinical signs of such inflammatory disorder include gouty flares that represented by quite pain, edema, warmness, and redness [8]. Persisting of hyperuricemia leads to further MSU deposits crystals inducing chronic inflammatory responses that may lead to the tophi formation, chronic joint destruction, renal insufficiency, and cardiovascular problems $[9,10]$. Therapeutic management of gout involves two methods of treatment: The first one is rapid and aims to cure the nociception and inflammation caused by acute inflammatory attacks of gout, while the second method involves the reducing the levels of UA in the blood into normal values in a long-term manner $[5,11]$. The first approach to treatment comprises many types of drugs such as nonsteroidal anti-inflammatory drugs (NSAIDs), colchicine, and corticosteroids; however, prolonged use of these drugs may produce critical side effects such as ulcerations and toxicity of gastrointestinal tract and renal toxicity [1]. The second approach of gout treatment, urate-lowering drugs (ULD) includes two categories of drugs: (a) XO inhibitors such as allopurinol and febuxostat and (b) uricosurics agents such as probenecid and benzbromarone. In general, XO inhibitors are indicate to urate-overproduction patients, whereas uricosurics drugs are prescribe to urate-underexcretion patients. Although the use of ULD medication is effective in gout cure, but not without adverse effects such as severe hypersensitivity reactions, hepatotoxicity and renal defects [12]. Until now, although severity and serious complications of gout, there are still a few drugs that are used in the treatment, in addition to the serious side effects for many of these drugs. Therefore, it necessary to search for new effective and safe urate-lowering agents with analgesic, antioxidant, and anti-inflammatory activities [13,14].

Alpha-lipoic acid ( $\alpha$-[LA]; also named as thioctic acid) is a dithiol substance existing in animals and plants that function as a coenzyme for the several enzymes of the energy-producing metabolism in the mitochondria $[15,16] . \alpha$-LA acts as a potent antioxidant in the all parts of cellular environments due to its good solubility in both water and lipid [17]. In the different tissues of the human body, $\alpha$-LA is rapidly changed into the reduced status, dihydrolipoic acid (DHLA) that works as more active than $\alpha$-LA itself $[18,19]$. As well as the valuable antioxidant activity, $\alpha$-LA and DHLA possess many different biological activities like the regeneration ability of other antioxidants (Vitamin E and $\mathrm{C}$ and glutathione) from oxidized forms into active reduced states, 
also these acids are effective chelators of toxic metals and male fertility enhancers. Many studies revealed the ability of $\alpha$-LA in the treatment and prevention of different oxidative-mediated pathological defects such as inflammation, diabetes neuropathy, cells aging, and cardiovascular diseases [20-22]. According to the potent antioxidant activity of $\alpha$-LA, this study aimed to investigate the antinociception, anti-inflammatory and antihyperuricemic activity of $\alpha$-LA in the gouty arthritis model in the rats.

\section{MATERIALS AND METHODS}

\section{Animals}

This study included the use of two types of animals and male in gender: Wistar rats (150-170 g) and albino Swiss mice. (25-30 g) which were supplied from the unit of animals' house at College of Pharmacy, Basrah University. Both rats and mice were separated into different groups $(n=6)$, then the animals were accommodated in isolated plastic cages and kept in the animal's room under a regulated condition at temperature $25 \pm 2{ }^{\circ} \mathrm{C}$ and humidity $30 \pm 15 \%$ with the 12 -h dark/12-h light cycle for a week before being used for acclimatization. They were fed standard chow and water ad libitum, and all of dealing procedures with animals that described in this study were authorized by Animal Ethics Committee, University of Basrah, Iraq (No. 2013/32).

\section{In vitro $\mathrm{XO}$ inhibitory activity}

The XO inhibitory effect of $\alpha$-LA was assessed spectrophotometrically at $290 \mathrm{~nm}$ according to Sunarni et al. [23] and Yumita et al. [24] with minor changes. The mixture assay consists of $0.9 \mathrm{~mL}$ of $0.05 \mathrm{M}$ sodium phosphate buffer (pH 7.5 at $\left.25^{\circ} \mathrm{C}\right), 1 \mathrm{~mL}$ of $\alpha$-LA solution $(100 \mu \mathrm{g} / \mathrm{mL}$ in DMSO), and $0.1 \mathrm{~mL}$ of XO enzyme solution $(0.1 \mathrm{unit} / \mathrm{mL}$ in phosphate buffer, pH 7.5) was prepared in cold buffer directly before using. After a 15 -min preincubation at $25^{\circ} \mathrm{C}$, the reaction was started by addition of $2000 \mu \mathrm{L}$ of a freshly prepared solution of substrate $0.15 \mathrm{~mm}$ xanthine solution). Next, a further incubation process was achieved for the reaction mixture at $25^{\circ} \mathrm{C}$ for $30 \mathrm{~min}$. After addition of $1 \mathrm{~mL}$ of $1 \mathrm{~N} \mathrm{HCl}$ solution into assay mixture for stopping the reaction, the absorbance was recorded at wavelength $290 \mathrm{~nm}$ using UV/Vis spectrophotometer against the blank which is prepared in the same procedure but with the replacement of enzyme solution by phosphate buffer. The positive control solution was prepared using allopurinol $(100 \mu \mathrm{g} / \mathrm{mL})$ in DMSO. The inhibitory activity of XO was established as the inhibition percentage $(\%)$ :

$\%$ XO inhibition $=(1-\alpha / \beta) \times 100$

Where $\alpha$ is the activity of XO without tested substance ( $\alpha$-LA) and $\beta$ is the activity of XO with the presence of $\alpha$-LA.

Different concentrations of both $\alpha$-LA and allopurinol $(100,50,25$, $10,5,4,3,2$, and $1 \mu \mathrm{g} / \mathrm{mL}$ ) were used for evaluation of XO inhibitory activities; then, the dose-response logarithmic curve was applied to determine the median maximum inhibitory concentration $\mathrm{IC}_{50}$.

\section{Drug administration}

Allopurinol and $\alpha$-LA were suspended in $0.5 \%$ sodium salt of carboxymethyl cellulose, $\mathrm{Na}$ (vehicle). Potassium oxonate $(250 \mathrm{mg} / \mathrm{kg}$ ), indomethacin ( $3 \mathrm{mg} / \mathrm{kg})$, and MSU crystals $(40 \mathrm{mg} / \mathrm{mL})$ were suspended in $0.9 \%$ sterile saline. All solutions were prepared freshly before use for in vivo experiments.

\section{Evaluation of antihyperuricemic activity}

The antihyperuricemic activity of $\alpha$-LA investigated using the potassium oxonate-induced hyperuricemia in the rat's model according to Haidari et al. [25] and Nguyen et al. [26] with modifications. Animals were fasted by withdrawing of food and water $2 \mathrm{~h}$ before drugs administration. Experimental animals (rats) were divided randomly into six groups $(n=6)$. The uricase inhibitor (potassium oxonate) at a dose of $250 \mathrm{mg} / \mathrm{kg}$ was injected intraperitoneally (i.p.) to rats of groups (2-6) in the $1^{\text {st }}, 3^{\text {rd }}$, and $7^{\text {th }}$ days of the experiment period. Rats groups were administered with oral treatments of the vehicle, allopurinol, and $\alpha$-LA solutions by oral gavage $1 \mathrm{~h}$ after the administration of potassium oxonate, once a day for 7 consecutive days of the experiment. Animals of normal control (Group 1) and hyperuricemic control (Group 2) were received the only vehicle through oral administration. Standard drug group (Group 3) was treated orally with allopurinol (10 mg/kg). Sample Groups 4-6 were treated orally with $\alpha$-LA at the doses 10,25 , and $50 \mathrm{mg} / \mathrm{kg}$, respectively, once a day, throughout the days of the experiment. Whole blood samples were collected from each rat by cutting tail vein $2 \mathrm{~h}$ after last administration of tested drugs. The blood was permitted to clot for $0.5 \mathrm{~h}$ at room temperature and then centrifuged at $3500 \mathrm{rpm}$ for $5 \mathrm{~min}$ to get the serum. The sera were stored at $-20^{\circ} \mathrm{C}$ until the UA is assayed.

\section{UA assay}

The enzymatic-colorimetric method employed to determine the serum UA levels using a standard diagnostic kit (BioLab., France).

\section{Anti-inflammatory effect of $\alpha$-LA on gouty arthritis inflammation model in mice}

An experimental model of gout as previously mentioned by Lima etal. [27] and Ferrari et al. [28] with some modifications carried out to investigate the anti-inflammatory effect of $\alpha$-LA. The assay was performed within a period of 3 days. Animals (mice) were distributed into six groups $(n=6)$. On the $1^{\text {st }}$ day of the study, the inflammatory induction was achieved by intradermal injection of $100 \mu \mathrm{L}(4 \mathrm{mg})$ of MSU crystals suspension into the right hind paws of mice. All groups of animals (2-6) were injected with MSU, except for normal control group (Group 1), which were injected with $100 \mu \mathrm{L}$ of $0.9 \%$ sterile saline solution. All treatments were administered by oral gavage an hour before injection of MSU suspension on the $1^{\text {st }}$ day of the experiment and repeated a once daily at the same time, for another 2 days. Mice of Group 1 and Group 2 were treated with the vehicle and served as normal control group and MUS-induced gouty (negative) control group, respectively. Group 3 animals were treated with a standard nonsteroidal anti-inflammatory agent, indomethacin ( $3 \mathrm{mg} / \mathrm{kg}$ ) and served as a positive control group. Mice of groups (4-6) were treated with $\alpha$-LA at the doses 10,25 , and $50 \mathrm{mg} / \mathrm{kg}$. Thickness of mouse hind paw was measured with digital Vernier caliper (Numit, China) at $0,4,24$, and $48 \mathrm{~h}$ after MUS injection and the inflammatory edema were expressed as a percentage of thickness variation $(\Delta)$.

\section{Evaluation of analgesic activity of $\alpha$-LA Writhing test}

This test performed as formerly explained by Spindola et al. [29] with modifications. Male albino mice were distributed into five groups each containing five mice. Animals were fasted for overnight and then were treated as following: Group 1 of mice were treated $(10 \mathrm{~mL} / \mathrm{kg})$ of vehicle $(0.9 \%$ saline solution) and served as negative control group and Group 2 of mice were treated $10 \mathrm{mg} / \mathrm{kg}$ of indomethacin and served as positive control group, while mice groups (3-5) were received 10, 25, and $50 \mathrm{mg} / \mathrm{kg}$ of $\alpha$-LA, respectively. All treatments of vehicle, indomethacin, and $\alpha$-linoleic acid were given orally by gastric gavage. After of $1 \mathrm{~h}$, mice in all groups were treated with $10 \mathrm{~mL} / \mathrm{kg}$ of $1 \% \mathrm{v} / \mathrm{v}$ acetic acid solution intraperitoneally (i.p) to induce the nociception state (pain). $5 \mathrm{~min}$ after the giving of acetic acid, the number of observed writhings in each mouse was counted for $15 \mathrm{~min}$. The percentage inhibition (I\%) of writhing (abdominal constrictions) was used to evaluate the analgesia potency and was calculated as the following formula:

Inhibition \% $(\mathrm{I} \%)=\left(\mathrm{N}_{\mathrm{c}}-\mathrm{N}_{\mathrm{t}} / \mathrm{N}_{\mathrm{c}}\right) \times 100$

Where $\mathrm{N}_{c}$ is the average of writhing numbers in the negative control group and $\mathrm{N}_{\mathrm{t}}$ is the average of writhing numbers in the treated groups.

\section{Hot plate test in mice}

One of the evaluation methods of antinociception activity is the hot plate test in mice, which performed according to the previously described in the method of Schmidt et al. [30] with modifications. Five groups of Swiss albino mice of both sexes were used with six animals in each group in this experiment. Mice were fasted for overnight and then were treated as following: Group 1 of mice were treated $(10 \mathrm{~mL} / \mathrm{kg}$, p.o $)$ 
of vehicle $(0.9 \%$ saline solution) and served as negative control group and Group 2 of mice were intraperitoneally treated $10 \mathrm{mg} / \mathrm{kg}$ of tramadol and served as positive control group, while mice groups (35 ) were orally received 10,25 , and $50 \mathrm{mg} / \mathrm{kg}$ of $\alpha$-LA, respectively. $1 \mathrm{~h}$ of all treatments, mice were putted inside glass cylinder placed on the well-regulated hot plate maintained $55 \pm 1^{\circ} \mathrm{C}$, and the difference time between placing of mice on the surface of hot plate and the occurrence of fore hind paws licking or jumping was recorded as reaction time. It has been taken into consideration that the cutoff period should not exceed $20 \mathrm{~s}$ maximum latency to avoid the injury of paws.

\section{Statistical analysis}

The results of all trials in this study stated as mean \pm structural equation modeling. Statistical analysis carried out by (ANOVA) pursued by the Dennett's t-test. The values of probability $(P)<0.05$ are considered as statistically significant.

\section{RESULTS AND DISCUSSION}

\section{In vitro $\mathrm{XO}$ inhibitory activity}

The inhibitory effects of $\alpha$-LA and allopurinol for bovine milk XO at different concentrations represented in Table 1 . Each has revealed $>50 \%$ of $\mathrm{XO}$ inhibition at the concentration $4 \mu \mathrm{g} / \mathrm{mL}$. At highest concentration $100 \mu \mathrm{g} / \mathrm{mL}$, the $\alpha$-LA resulted in $88 \%$ of XO inhibition activity, whereas the standard XO inhibitor, allopurinol demonstrated $95 \%$ of XO inhibition activity at the same concentration. The XO inhibitory effects for both $\alpha$-LA and allopurinol were also stated in the term of $\mathrm{IC}_{50}$, which is represent the concentration of standard drug or tested sample that is required for $50 \%$ inhibition of XO enzyme activity under the same experimental conditions. The $\mathrm{IC}_{50}$ values were calculated according to the dose-response logarithmic curve using GraphPad Prism V 6.05 program (GraphPad Prism software, Inc., USA), where the value was equal to $1.734 \mu \mathrm{g} / \mathrm{mL}$ for allopurinol and $2.930 \mu \mathrm{g} / \mathrm{mL}$ for $\alpha$-LA, respectively, as shown in Fig. 1 .

\section{Antihyperuricemic activity}

To assess the existence of antihyperuricemic effect of the $\alpha$-LA, the potassium oxonate-induced hyperuricemia model in rats used in this study. As shown in Table 2, the intraperitoneal injection of uricase inhibitor, potassium oxonate $(250 \mathrm{mg} / \mathrm{kg})$ obviously increased the serum UA levels in rats compared with healthy normal control group. The administration of standard XO inhibitor, allopurinol $(10 \mathrm{mg} / \mathrm{kg}, \mathrm{p} . \mathrm{o})$, was able to significantly reduce $(\mathrm{p}<0.001)$ the serum UA levels of hyperuricemic rats (positive control group) to values close of normal control. The consecutive 7-day treatment of rats with $\alpha$-LA at the dose 10,25 , and $50 \mathrm{mg} / \mathrm{kg}$ significantly reduce $(\mathrm{p}<0.001)$ the serum UA levels as compared with hyperuricemic control group in all doses above.

\section{Effect of $\alpha$-LA on MSU crystal-induced inflammation in mice}

As shown in Table 3 , the injection of MSU crystals significantly increased $(p<0.001)$ the thickness of the mice paws when compared to the normal animal group. The injection of both standard NSAIDs, indomethacin $(3 \mathrm{mg} / \mathrm{kg})$, and $\alpha$-LA at all gradual doses $(10,25$, and $50 \mathrm{mg} / \mathrm{kg}$ ) was able to achieve a significant reduction $(\mathrm{p}<0.001)$ in the paw thickness at all periods of time assessment.

\section{Evaluation of analgesic activity of $\alpha$-LA Writhing test}

The results presented in Table 4 revealed that standard drug, indomethacin $(10 \mathrm{mg} / \mathrm{kg})$ significantly reduced the number of acetic acid-induced writhings in mice $(75 \%)$ compared to the negative control group $(\mathrm{p}<0.001)$. Similar to indomethacin, $\alpha$-LA at 10 and $25 \mathrm{mg} / \mathrm{kg}$ was able to produce a significant antinociception effect $(\mathrm{p}<0.001)$ by reducing the number of writhings in mice ( $52 \%$ and $67 \%$, respectively), while at $50 \mathrm{mg} / \mathrm{kg}$, the $\alpha$-LA showed higher capacity than indomethacin $(79 \%)$ in reduction of the writhings number in mice induced by injection of acetic acid.
Table 1: X0 inhibitory activity of $\alpha$-LA and allopurinol at different concentrations

\begin{tabular}{lll}
\hline Concentration $(\boldsymbol{\mu g} / \mathbf{m L})$ & $\begin{array}{l}\text { XO inhibitory activity }(\%) \\
\text { (mean } \pm \text { SEM) }\end{array}$ \\
\cline { 2 - 3 } & Allopurinol & $\boldsymbol{\alpha}$-LA \\
\hline 100 & $95 \pm 1.5$ & $88 \pm 2.2$ \\
50 & $89 \pm 0.6$ & $81 \pm 0.7$ \\
25 & $80 \pm 1.1$ & $73 \pm 1.8$ \\
10 & $73 \pm 2.1$ & $62 \pm 1.4$ \\
5 & $67 \pm 2.0$ & $59 \pm 0.3$ \\
4 & $61 \pm 0.4$ & $53 \pm 0.2$ \\
3 & $55 \pm 0.6$ & $49 \pm 1.1$ \\
2 & $53 \pm 1.6$ & $46 \pm 0.8$ \\
1 & $44 \pm 1.2$ & $38 \pm 0.7$ \\
\hline SEM: Standard error of the $m e a n$, L $~$ &
\end{tabular}

SEM: Standard error of the mean, LA: Lipoic acid, XO: Xanthine oxidase

Table 2: Effects of allopurinol and $\alpha$-LA on the serum UA levels in the normal and potassium oxonate-induced hyperuricemic rats

\begin{tabular}{llll}
\hline Group & Dose $(\mathbf{m g} / \mathbf{k g})$ & n & Serum UA (mg/dL) \\
\hline Normal control & - & 6 & $1.2 \pm 0.2$ \\
Hyperuricemic control & - & 6 & $4.4 \pm 0.7$ \\
Standard drug (Allopurinol) & 10 & 6 & $1.7 \pm 0.6^{* * *}$ \\
Test $(\alpha-\mathrm{LA})$ & 10 & 6 & $2.3 \pm 0.4^{* * *}$ \\
& 25 & 6 & $2.1 \pm 0.5^{* * *}$ \\
& 50 & 6 & $1.9 \pm 0.3^{* * *}$ \\
\hline
\end{tabular}

Each value is the mean \pm SEM, ${ }^{*} \mathrm{p}<0.05,{ }^{* *} \mathrm{p}<0.01,{ }^{* * *} \mathrm{p}<0.001$ compared with hyperuricemic control. Data analyzed by using one-way ANOVA followed by Dennett's test, SEM: Standard error of the mean, LA: Lipoic acid, UA: Uric acid

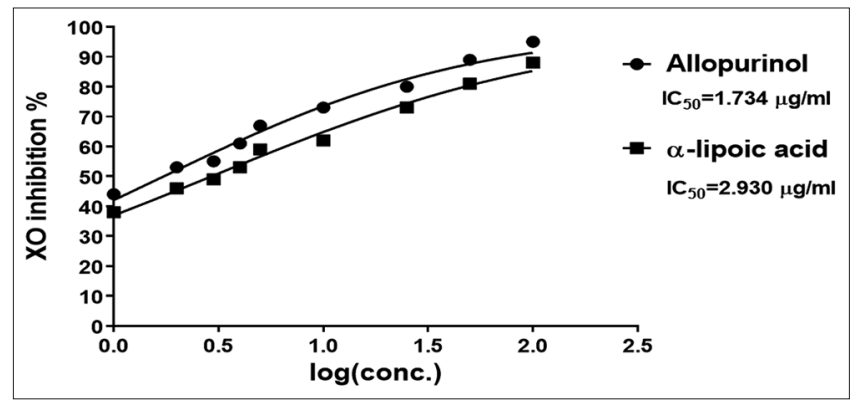

Fig. 1: Xanthine oxidase inhibitory activity and IC $_{50}$ values of $\alpha$-lipoic acid and allopurinol

\section{Hotplate test}

The mean reaction time of pain responses to the thermal stimuli in the hot plate test is shown in Table 5. Three doses of $\alpha$-LA (10, 25, and $50 \mathrm{mg} / \mathrm{kg}$, p.o.) significantly increased $(\mathrm{p}<0.001)$ the reaction times to the heat-induced pain in mice compared to the negative control group (vehicle). Positive drug, tramadol (10 m g/kg, s.c.) markedly increased $(p<0.001)$ the mean of reaction times from $3.14 \mathrm{~s}$ at negative control group to $11.65 \mathrm{~s}$.

\section{DISCUSSION}

Gout is a chronic inflammatory condition associated with the deposition of sodium urate crystals, resulting in severe pain and swollen joints and soft tissue. Treatment methods for gout management include the first treatment of acute gout attacks involving the use of anti-inflammatory and analgesic agents such as NSAIDs, colchicine, and corticosteroids. Subsequently, the lowering urate drugs such as allopurinol, febuxostat, and probenecid are used to treat hyperuricemia. Until now, the use of these drugs involves the emergence of many side effects, and none of the clinically available drugs can be used to treat the 
Table 3: Effect of $\alpha$-LA on MSU crystals-induced inflammation hind paw in mice

\begin{tabular}{llll}
\hline Group & Dose $(\mathbf{m g} / \mathbf{k g})$ & \multicolumn{2}{c}{ Thickness variation $\boldsymbol{\Delta}$ (mm) in paw edema } \\
\cline { 3 - 4 } & & $\mathbf{4 h}$ & $\mathbf{2 4} \mathbf{~ h}$ \\
\hline Normal control & - & $0.2 \pm 0.11$ & $0.17 \pm 0.07$ \\
Negative control & - & $1.81 \pm 0.25$ & $1.52 \pm 0.19$ \\
Indomethacin & 3 & $0.32 \pm 0.12^{* * *}$ & $0.47 \pm 0.18^{* * *}$ \\
$\alpha$-LA & 10 & $0.66 \pm 0.10^{* * *}$ & $0.84 \pm 0.21^{* * *}$ \\
& 25 & $0.57 \pm 0.09^{* * *}$ & $0.69 \pm 0.08^{* * *}$ \\
& 50 & $0.41 \pm 0.17^{* * *}$ & $0.06 \pm 0.13$ \\
\hline
\end{tabular}

Each value is the mean \pm SEM for six mice, ${ }^{*} \mathrm{p}<0.05,{ }^{* *} \mathrm{p}<0.01,{ }^{* * *} \mathrm{p}<0.001$ compared with normal control. Data analyzed by using one-way ANOVA followed by Dennett's test, SEM: Standard error of the mean, LA: Lipoic acid, MSU: Monosodium urate

Table 4: Antinociceptive effect of $\alpha$-LA on the acetic acid-induced writhings in mice

\begin{tabular}{llll}
\hline Group & Dose (mg/kg) & Number of writhings & Inhibition (\%) \\
\hline Negative control (vehicle) & - & $46.31 \pm 3.24$ & - \\
Positive control (indomethacin) & 10 & $11.22 \pm 1.62^{* * *}$ & 75.77 \\
$\alpha$-LA & 10 & $21.82 \pm 1.12^{* * *}$ & 52.88 \\
& 25 & $15.01 \pm 2.71^{* * *}$ & 67.58 \\
& 50 & $9.43 \pm 1.10^{* * *}$ & 79.63 \\
\hline
\end{tabular}

Each value is the mean $\pm \mathrm{SEM},{ }^{*} \mathrm{p}<0.05,{ }^{* *} \mathrm{p}<0.01,{ }^{* * *} \mathrm{p}<0.001$ compared with negative control. Data analyzed by using one-way ANOVA followed by Dennett's test, SEM: Standard error of the mean, LA: Lipoic acid

Table 5: Antinociceptive effect of $\alpha$-LA by hot plate method in mice

\begin{tabular}{lll}
\hline Group & Dose (mg/kg) & $\begin{array}{l}\text { Reaction } \\
\text { time (seconds) }\end{array}$ \\
\hline Negative control (vehicle) & - & $3.14 \pm 0.57$ \\
Positive control (tramadol) & 10 & $11.65 \pm 0.18^{* * *}$ \\
$\alpha$-LA & 10 & $5.22 \pm 0.28^{* * *}$ \\
& 25 & $6.86 \pm 0.36^{* * *}$ \\
& 50 & $7.51 \pm 0.62^{* * *}$ \\
\hline
\end{tabular}

Each value is the mean \pm SEM, ${ }^{*} \mathrm{p}<0.05,{ }^{* *} \mathrm{p}<0.01,{ }^{* * *} \mathrm{p}<0.001$ compared with negative control. Data analyzed by using one-way ANOVA followed by Dennett's test, SEM: Standard error of the mean, LA: Lipoic acid

gout arthritis symptoms together such as pain, hyperuricemia, and inflammation [10]. The present study aimed to investigate the XO inhibitory, antihyperuricemic, anti-inflammatory, and antinociception activity of $\alpha$-LA

UA produced as a main final product of purine metabolism by the action of XO enzyme that accelerates the hypoxanthine conversion to xanthine and then xanthine into UA. Therefore, the inhibition of XO activity can be considered as a useful therapeutic method in the treatment of gout and other XO-related complications [25]. Different concentrations of $\alpha$-LA and allopurinol were assessed for in vitro bovine milk XO inhibitory activity. The $\mathrm{XO}$ inhibition percentage results are revealed in Table 1 indicated that at the final concentration $100 \mu \mathrm{g} / \mathrm{mL}$, the $\alpha$-LA potentially inhibited the XO activity with $88 \%$ as compared to $95 \%$ for the standard drug, allopurinol at the same concentration. Further, the $\mathrm{IC}_{50}$ value for the $\alpha$-LA $(2.93 \mu \mathrm{g} / \mathrm{mL})$ clearly denotes that it is a potent $\mathrm{XO}$ inhibitor as compared with the value of well-known XO inhibitor, allopurinol $\left(\mathrm{IC}_{50}=1.73 \mu \mathrm{g} / \mathrm{mL}\right)$.

Potassium oxonate is a well-known uricase inhibitor in animal models of hyperuricemia due to low-cost and rapid-acting substance. The potassium oxonate-induced hyperuricemic rats are the most suitable animal model to assess new drugs that affect levels of UA in the blood [31]. In this study, treatment of rats with potassium oxonate resulted in a significant elevation in the serum urate levels as compared to normal group, revealing that the rat model has been successfully established. A 7-day oral treatment of the $\alpha$-LA at doses $(10,25$, and $50 \mathrm{mg} / \mathrm{kg})$ significantly decreased $(\mathrm{p}<0.001)$ in a dose-dependent mode the serum UA levels when associated with the hyperuricemic control group. In contrast, the same treatment with the standard hypouricemic drug, allopurinol $(10 \mathrm{mg} / \mathrm{kg})$ also led to a significant reduction $(\mathrm{p}<0.001)$ in serum urate levels. The reduction in the serum UA levels and proceeded by a significant efficacy of inhibition of $\mathrm{XO}$, these results designate that the overall activity of the $\alpha$-LA as antihyperuricemic is markedly associated with inhibition of XO activity, and this may be the mechanism of action.

In this study, MSU crystal-induced inflammation model used to trigger the occurrence of gout acute attacks through the accumulation of the urate crystals in the joints, promoting the initiation of a series of inflammatory reactions, which, in turn, result in acute inflammation and tissue damage [32]. Injection of the MSU crystals produced an important increase in the thickness of mice hind paws as matched to the negative control. Treatment with both indomethacin at a dose $(3 \mathrm{mg} / \mathrm{kg})$ and $\alpha$ - LA at doses $(10,25$, and $50 \mathrm{mg} / \mathrm{kg}$ ) resulted in significant reduction in the thickness of mice paws at 4,24 , and $48 \mathrm{~h}$ of injection of MSU crystals. These results confirm the ability of $\alpha$-LA to block the synthesis and releasing of inflammatory mediators because the $\alpha$-LA can work efficiently in the initial and last stages of the inflammatory process.

The antinociception activity of new drugs can verify by assessing their effects centrally or peripherally, where the hot plate test used to evaluate the central acting analgesic effect and the acetic acid-induced writhings test used to evaluate the peripheral acting analgesic effect [33]. In the present study, we employed both techniques to not only verify antinociceptive influence but also to determine the mechanism action of the antinociceptive effect of $\alpha$-LA. The inhibition of the acetic acidinduced writhings is an indication of potential analgesic of $\alpha$-LA. The pain induction by acetic acid is due to liberating endogenous substances such as histamine, serotonin, prostaglandins, and bradykinins and those which stimulate nerve endings [29]. Thus, the antinociceptive effect of $\alpha$-LA may be peripherally mediated by the inhibition of synthesis and liberating of prostaglandins through inhibition of cyclooxygenase enzymes. Since acetic acid-induced contractions test involves several different types of nociceptive mechanisms, we have tested the hot plate to assess the possibility of $\alpha$-LA from showing any central analgesic effect. The ability of $\alpha$-LA to lengthen the reaction latency to the thermal-induced pain of mice by the hot plate strongly supports its most central analgesic activity. Consequently, $\alpha$-LA may exhibit its antinociceptive effect by involving peripheral and central mechanisms.

\section{CONCLUSIONS}

The results of the current study demonstrated that the $\alpha$-LA has remarkable effects in the treatment of gout and associated diseases. It was noted that it was able to potentially reduce the urate levels in the 
serum of potassium oxonate-induced hyperuricemic rats through the potent inhibitory activity for XO in vitro. Furthermore, $\alpha$-LA was able to reduce MSU crystal-induced edema hind paw in mice significantly. Furthermore, $\alpha$-LA possesses significant efficient as peripheral and central analgesic agent through acetic acid-induced writhing and hot plate tests.

\section{AUTHOR'S CONTRIBUTIONS}

Both authors have the same contribution to this research by implementing search, data collection, data analysis, and format manuscript.

\section{CONFLICTS OF INTEREST}

There are no conflicts of interest.

\section{REFERENCES}

1. de Souza MR, Paula CA, Resende ML, Grabe-Guimãras A, Filho JD, Saúde-Guimãras DA. Pharmacological basis for use of Lychnophora trichocarpha in gouty arthritis: Anti-hyperuricemic and anti-inflammatory effect of its extract, fraction and constituents. J Ethnopharm 2012;142:845.

2. Maiuolo J, Oppedisano F, Gratteri S, Muoscoli C, Mollace V. Regulation of uric acid metabolism and excretion. Int J Cardiol 2016;213:8.

3. Kostić DA, Dimitrijević DS, Stojanović GS, Palić IR. Xanthine oxidase: Isolation, assays of activity, and inhibition. J Chem 2015;2015:294858.

4. Jin M, Yang F, Yang I, Yin Y, Luo JJ, Wang H, et al. Review: Uric acid, hyperuricemia and vascular diseases. Front Biosci 2012;17:656-69.

5. Batchu UR, Mandava K. Review: Biochemical role of oxidoreductase and its natural inhibitors. Int J Pharm Pharm Sci 2016;8:57-65.

6. Yiying K, Yongfang L, Husai M, Wangyu L, Ruilian L, Zhancui D. Uric acid lowering effect of Tibetan medicine Rupeng 15 powder in animal models of hyperuricemia. J Tradit Chin Med 2016;36:205

7. Haddi R, Marouf A. Xanthine oxidase inhibitory effects of Pistacia lentiscus L. leaves extracts. Int J Pharm Pharm Sci 2015;7:34-9.

8. Araújo MC, Ferraz-Filha ZS, Ferrari FC, Saúde-Guimarães DA. Campomanesia venlutina leaves extracts exert hypouricemic effects through inhibition of xanthine oxidase and ameliorate inflammatory response triggered by MSU crystals. Braz J Pharm 2016;26:720.

9. Dalbeth N, Merriman TR, Stamp LK. Gout. Lancet 2016;388:2039.

10. Zhao P, Chen KL, Zhang GL, Deng GR, Li J. Pharmacological basis for use of Selaginlla moellendorffii in gouty arthritis: Antihyperuricemic, anti-inflammatory and xanthine oxidase inhibition. Evid Based Complementary Altern Med 2017;4:1.

11. Saigal R, Agrawal A. Pathogenesis and clinical management of gouty arthritis. J Assoc Physicians India 2015;63:56.

12. Huang J, Wang S, Zhu M, Chen J, Zhu X. Effects of apigenin, quercetin, rutin and astilbin on serum uric acid levels and xanthine oxidase activities in normal and hyperuricemic mice. Food Chem Toxicol 2011:49:1943.

13. Qin Z, Wang S, Lin Y, Zhao Y, Yang S, Song J, et al. Antihyperuricemic effect of mangiferin aglycon derivative J99745 by xanthine oxidase activity and urate transporter 1 expression in mice. Acta Pharm Sin B 2017;8:306

14. Murugaiyah V, Chan KL. Mechanisms of antihyperuricemic effect of Phllanthus niruri and its lignin constituents. J Ethnopharm 2009; $124: 233$

15. Smith AR, Shenvi SV, Widlansky M, Suh JH, Hagen TM. Lipoic acid as a potential therapy for chronic diseases associated with oxidative stress. Curr Med Chem 2004;11:1135.
16. Goraca A, Huk-Kolega H, Kowalaczyk A, Skibska B. Anti-oxidative and anti-inflammatory of lipoic acid in rat liver. Postepy Hig Med Dosw 2015;69:270.

17. Salem HA, Shaffie NM. Possible protective effects of Vitamin E, $\alpha$-lipoic acid and lycopene in mercuric chloride-induced nephrotoxicity and hepatotoxicity in rats. J Egypt Soc Toxicol 2008;39:13.

18. Goraca A, Huk-Kolega H, Piechota A, Kleniewska P, Ciejka E, Skibska B. Lipoic acid-biological activity and therapeutic potential. Pharm Rep 2011;63:849.

19. Tibullo D, Volti GL, Giallongo C, Grasso S, Tomassoni D, Anfuso CD, et al. Review: Biochemical and clinical relevance of alpha lipoic acid: Antioxidant and anti-inflammatory activity, molecular pathways and therapeutic potential. Inflamm Res 2017;66:947.

20. Gomes MB, Negrato CA. Alpha-lipoic acid as a pleiotropic compound with potential therapeutic use in diabetes and other chronic diseases. Diabetol Metabol Syndr 2014;6:80.

21. Tastekin N, Aydogdu N, Dokmeci D, Usta U, Birtane M, Erbas H, et al. Protective effects of L-carnitine and alpha-lipoic acid in rats with adjuvant arthritis. Pharm Res 2007;56:303.

22. Haghighian HK, Haidari F, Mohammadi-Asl J, Dadfar M. A randomized, triple-blend, placebo-controlled clinical trial examining the effects of alpha-lipoic acid supplement on the spermatogram and seminal oxidative stress in infertile men. Ferti Steril 2015;104:318.

23. Sunarni T, Fidrianny I, Iwo MI, Wirasutina KR. Constituent and antihyperuricemic activity of Stelechocarpus burahol leaves subfractions. Asian J Pharm Clin Res 2017;10:435

24. Yumita A, Suganda AG, Sukandar EY. Xanthine oxidase inhibitory activity of some medicinal plants and active reaction of selected plants. Int J Pharm Pharm Sci 2013;5:293.

25. Haidari F, Rashidi MR, Keshavaraz SA, Mahboob SA, Eshraghian MR, Shahi MM. Effects of onion on serum uric acid levels and hepatic xanthine dehydrogenase/xanthine oxidase activities in hyperuricemic rats. Pak J Biol Sci 2008;11:1779.

26. Nguyen TD, Thuong PT, Hwang IH, Hoang TK, Nguyen MK, Ha N, et al. Anti-hyperuricemic, anti-inflammatory and analgesic effects of Siegesbeckia orientalis L. resulting from the fraction with high phenolic content. BMC Complementary Altern Med 2017;17:191.

27. Lima RC, Ferrari FC, de Souza MR, Pereira BM, de Paula A, SaúdeGuimarães DA. Effects of extracts of leaves from Sparattosperma leucanthum on hyperuricemia and gouty arthritis. J Ethnopharm 2015;161:194.

28. Ferrari FC, Lima RC, Filha ZS, Barros CH, Araújo MC, SaúdeGuimarães DA. Effects of Pimenta pseudocaryophyllus extracts on gout: Anti-inflammatory activity and anti-hyperuricemic effect through xanthine oxidase and uricosuric action. J Ethnopharm 2016;180:37.

29. Spindola HN, Vendramini-Costa DB, Fogilo MA, Pili R, Carvalho JE. The antinociceptive activity of harmicine on chemicalinduced neurogenic and inflammatory pain models in mice. Pharm Biochem Behav 2012;102:133.

30. Schmidt AP, Böhmer AE, Antunes C, Schallenberger C, Porciúncula LO, Elisabetsky E, et al. Anti-nociceptive properties of the xanthine oxidase in mice: Role of $\mathrm{A}_{1}$ adenosine receptors. Br J Pharm 2009;156:163.

31. Kong LD, Zhou J, Wen YL, Cheng CH. Asesclin possesses potent hypouricemic action in rodents but is devoid of xanthine oxidase/ dehydrogenase inhibitory activity. Planta Med 2002;68:175.

32. Rasool M, Varalakshmi P. Suppressive effect of Withamia somnifera root powder on experimental gouty arthritis: An in vivo and in vitro study. Chem Biol Interact 2006;164:174.

33. Kodithuwakku ND, Pan M, Zhu YL, Zhang YY, Feng Y, Fang W, et al. Anti-inflammatory and antinociceptive effects of Chinese medicine SQ gout capsules and its modulation of pro-inflammatory cytokines focusing on gout arthritis. J Ethnopharm 2013;150:1071. 